\title{
Spirituality, shifting identities and social change: Cases from the Kalahari landscape
}

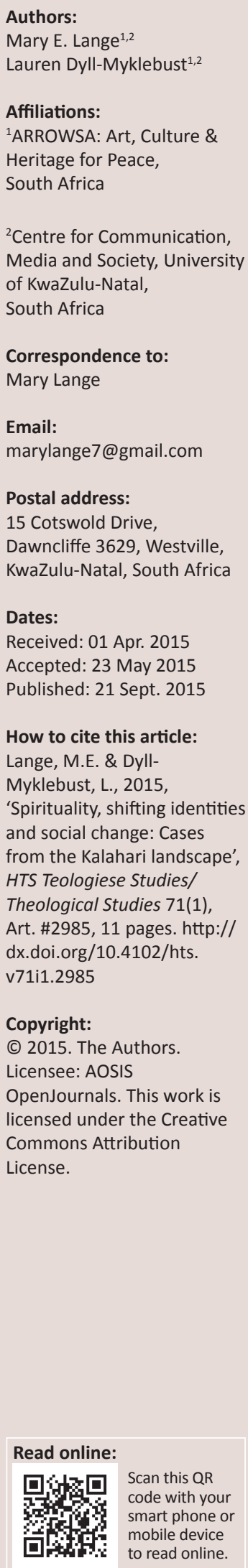

Storytelling, art and craft can be considered aesthetic expressions of identities. Kalahari identities are not fixed, but fluid. Research with present-day Kalahari People regarding their artistic expression and places where it has been, and is still, practised highlights that these expressions are informed by spirituality. This article explores this idea via two Kalahari case studies: Water Stories recorded in the Upington, Kakamas area, as well as research on a specific rock engraving site at Biesje Poort near Kakamas. The importance of the Kalahari People's spiritual beliefs as reflected in these case studies and its significance regarding their identities and influence on social change and/or community development projects is discussed. The article thus highlights ways in which spirituality can be considered in relation to social change projects that are characterised by partnerships between local community, non-government and tertiary education representatives and researchers and that highlight storytelling as an integral part of people's spirituality.

\section{Introduction}

Storytelling, art and craft can be considered aesthetic expressions of identities (Leuthold 1998). Research with present-day Kalahari People regarding their artistic expression and places where it has been, and is still, practised highlights that these expressions are informed by spirituality (Lange 2006; Lange et al. 2013). Kalahari identities are not fixed, but fluid (Dyll-Myklebust 2014; Ellis 2014; Simões 2001). This article explores this idea via two Kalahari case studies: Water Stories, that focus on the Water Snake, recorded in the Upington, Kakamas area (Hoff 1993, 1997; Lange 2011a, 2014), as well as research on a specific rock engraving site at Biesje Poort near Kakamas (Lange et al. 2013; Morris 2014). This engraving site is situated in

a landscape of hills that divide the Orange (Gariep) River Basin near Kakamas, in the Northern Cape, from the plains of the southern Kalahari fringe near Lutzputz. A number of rock engraving clusters occur on expansive rock exposures embedded in the hills. (Morris 2014:649)

The importance of the Kalahari People's spiritual beliefs as reflected in these case studies, and its significance regarding their identities and influence on social change projects, is discussed. The article thus highlights ways in which spirituality can be considered in relation to social change projects that are characterised by partnerships between community, non-government and tertiary education representatives and researchers, and the potential role of art and/or storytelling as 'vehicles for spiritual expression and exploration' (Guion 2008:34; see also Grant \& Dicks 2014).

\section{Locating shifting identities and spirituality in social change/community development}

Our research subscribes to the idea that spirituality is considered inseparable from identity (MacDonald 2009; Wilber 2000). Considering the influences of modernisation and globalisation, identity is considered 'pluralised', dynamic and constructed (Hall 1992, 1997; Nicholson 2009b). These concepts dispel the idea of a single identity and rather promote a sliding between different identities determined by context. Further to this Stuart Hall (1992) proposes that identities are determined by 'difference' by the onlooker, rather than determined by the individual who holds a particular identity. The term 'Kalahari People' is used for the inhabitants of the research area as it has been a melting pot of cultures, races and language groups for the past approximately 2000 years (Smith 1995). The Group Areas Act of 1950 in South Africa 'restricted ownership and the occupation of land to a specific statutory group'. Prior to this Act many people of mixed descent (designated as mixed race) lived in mixed areas, 'onderdorpe' with black and white people ${ }^{1}$. The designated race and related terminology for Khoesan descendants during colonial rule and the apartheid regime is complex and reflects the diversity of roots within Southern Africa (Adhikari 
2009). Studies with people of Khoesan descent, specifically of the $\neq$ Khomani Kruiper family from within and south of the Kgalagadi Transfrontier Park (KTP), have found that shifting identities are largely due to displacement, social and political influences, access to resources, and development or social change opportunities (Ellis 2014; Simões 2001; Tomaselli 2005; White 1995).

From a development or social change communication perspective issues of culture and identity, as attached to spirituality, are embedded in research that focuses on the role of storytelling in allowing multiple voices to be heard, and hence these shifting identities and manifestations of spirituality, to be acknowledged (see Dutta 2011; DyllMyklebust 2014; Lange 2011a, 2014; Winskell \& Enger 2014). Multiple voices or multivocality includes the voices of not only academics and researchers but also those of illiterate or community members with limited education with a view to not only including scientific but also indigenous knowledge (Hodder 1999). The importance of this lies in its transformative impulse as it challenges the hegemony of the mainstream and 'offers an entry point for listening to the voices at the margins' (Dutta 2011:7; Spivak 1988). This complements a heritage recording and communication approach that is inclusive of the intangible and 'multivocal' in that it addresses not only previously excluded phenomenology of the marginalised, ethical issues and ordinary day practices (Marstine, Bauer \& Haines 2011), but it also promotes the sources' accessibility to their knowledge (Masoga \& Kaya 2011). In contemporary literature, 'development' is often replaced with 'social change' (Dutta 2011; Figueroa et al. 2002; Gumucio-Dagron \& Tufte 2006; Servaes 2008). The term accounts more closely for the intangible processes and manifestations of change, as opposed to the connotations of infrastructure, economic growth and authoritarian Western communication processes which are often automatically associated with the term 'development' (Dyll-Myklebust 2014:527). We thus see this as an opportunity to consider the role of spirituality and its concomitant effect on cultural identities within the field of social change communication.

Definitions of spirituality vary (Hocheimer 2011; Teasdale 1999; Tisdell 2003). Spirituality, in our work, is broadly equated to the concept of 'the Life Force' where the interconnectedness of the physical body, mind and soul (or spiritual self) is perceived and 'we sense its presence as love, compassion, and humility, as shared sacrifice. The perception of that life force... $[i s]$ that there is something greater, deeper, more profound out there among us' (Hocheimer 2011:2). Expressed simply, it is the perception and expression of connection to self and others, a higher being/s and the world and/or environment around us (Crisp 2010). Spirituality, if separated from religious practices, includes a common desire for transformation from 'self-interest to other-centeredness' (Teasdale 1999).

Before moving on to illustrate the role of spirituality in social change as well as its manifestation in artistic expression and its link to identity within the two case studies, it is important to briefly discuss how spirituality is only now emerging as part of the social sciences research agenda (outside of Theology). Historically, social change literature and practices 'have systematically avoided the topic of spirituality' (Ver Beek 2000:31). The reason for this is that spirituality is unquantifiable and has hence been perceived a 'development taboo' (Ver Beek 2000). From Western and/or Northern organisationally-based development perspective and praxis, the role of communication in effecting change is framed with an overall economic framework and objectives are generated from a performance-based, technocratic and impersonal standpoint. Non-material considerations in development communication, that is the realm of the spiritual, are seldom priorities in mainstream, secular Western development scholarship and practices. Not only has spirituality been unrepresented in field practices and social change literature, but traditions, community views and attitudes of 'traditional societies' have been viewed as inimical to progress (see Melkote \& Steeves 2001).

There have been pioneers who have highlighted the need for sensitivity to spirituality (see Denzin, Lincoln \& Smith 2008), but its import and impact need to be studied more systematically. In the 1970s the issue of 'spirit' in development was flagged when the Dag Hammarskjold ${ }^{2}$ Foundation urged for development to be more than industrial, but a process involving the 'whole person' - the self, society and spirit, thus challenging the top-down, linear, 'rational' model of social change. However, there has either been a paucity of practitioners and researchers that have taken this into consideration, and where it has been considered 'spirituality', is frequently thought to be synonymous with religion. Leslie Melkote and Srinivas Steeves (2001:274-295) note studies that have traversed the Western secular orientation of a separation between material and spiritual concerns in development. These studies include an analysis of the role of religion in development projects.

This liberation theology actively supports development for personal and collective empowerment and is largely associated with Christianity, but there are some examples of 'liberation arguments' in other major religions, predominantly Buddhism, Islam, Hinduism, and Judaism (Ellis 1990; Esack 1997; Knott 1998; Wielenga 1999). These arguments speak to poverty and racial, ethnic and sexual discrimination, and are influenced by Marxist philosophy (see Guttiérez 1973). Melkote and Steeves's (2001) review focuses on these most significant belief systems that affect development in that they account for the majority of the world's religion ${ }^{3}$. They do recognise other religious organisations, beliefs and motivations but space does not allow for inclusion of their analysis.

This article addresses the gap - not in that it delves into a specific 'less represented' religion, but that it includes these 'other beliefs' that are not in themselves a formal religion.

2.A Swedish diplomat, economist, and author. The second Secretary-General of the United Nations, he served from April 1953 until his death in an aeroplane crash in September 1961.

3.A bias to be aware of (see Bah 2008) 
It seeks to explore the wider understanding of 'spirituality' within social change where spirituality may be seen as

a relationship with the supernatural or spiritual realm that provides meaning and a basis for personal and communal reflection, decisions, and action. While religion is generally considered an institutionalised set of beliefs and practices regarding the spiritual realm, spirituality describes the personal and relational side of those beliefs, which shape daily life. (Ver Beek 2000:32)

Disciplines that have paid some attention to not only religion and religious practices, but also to spiritual beliefs and social change specifically relating to well-being, are Heritage Studies (Hodder 2010) and Social Work (Crisp \& Beddoe 2013), with the latter arguably leading the field (Groen 2009). Well-being is defined as the delicate, fluid balance between an individual or community's resources and challenges (Dodge et al. 2012). Oral narratives/reminiscences/history and rock art, including engravings, are considered intangible and tangible heritage in South Africa (South African National Heritage Act No. 25 of 1999). Heritage, and the recording and communication thereof, should be of social and not just aesthetic value and should be protected because the aesthetic value is influenced by 'a particular social context in which they are of consequence to well-being' (Hodder 2010:77). The recording of oral heritage therefore emulates, to a certain degree, the original social role that orality played within the community. As an expression of spirituality, orality and/or storytelling provides a needed non-judgemental space for the sharing of spiritual beliefs, especially where they may differ from those held by the majority (Crisp \& Beddoe 2013). The positive outcomes of the expression of spirituality, as in religious practices, include 'facilitating connectedness, establishing a sense of identity, providing structures for quiet reflection, finding a sense of meaning or experiencing transcendence' (Crisp \& Beddoe 2013:115). Orality, therefore, in the form of reminiscences or storytelling promotes not only the construction of individual identity but also social cohesion and further provides a needed space both historically and in the present for women's voices (Prado 2010) and the challenging of gender power relations in everyday life (Lange 2011a).

Research upon which this article is based involved observations of these above-mentioned forms of daily life and relations of 'power' (both spiritual and between groups) and how these may be negotiated for the purpose of a common goal (Magongo 2013); gathering local Water Stories and collecting an intercultural tapestry of stories and interpretations related to an under-researched rock engraving site. In so doing these projects facilitate social change in that they provide platforms for oft-marginalised and subaltern voices (Dutta 2011; Spivak 1988).

\section{The cases: Water Stories of the !Garib River and rock engravings in Biesje Poort}

The article draws on two case studies linked to the Kalahari People north of the Orange/!Garib River. The first is based on the taped and videoed recordings of Water Stories in 1998 by a group of women of mixed descent who live in Upington, situated in the Green Kalahari, Northern Cape (Lange 2011a, 2014). The second is a rock engraving recording project based on the farm Biesje Poort near Kakamas, also situated in the Green Kalahari, Northern Cape (Lange et al. 2013; Morris 2014; Tomaselli \& Dyll-Myklebust [in press]). The latter case study included academics and local people, specifically from the Kruiper and Org families ${ }^{4}$ who are made up of indigenous San $\neq$ Khomani and mixed descent.

The complex identity of people north of the Orange River in the Green Kalahari area who are included in the case studies is influenced by the factors discussed in the previous section regarding Kalahari People. These complexities are reflected in Johanna (Nana) de Wee's description of her roots. Nana is one of the Upington storytellers who contributed to the oral heritage record of Water Stories that recount experiences related to the Water Snake in the !Garib (Orange) River:

My ma is 'n Baster-Kleurling-Hotnosvrou. My ma se naam is Katrina en sy van is DeWee. Sy kom uit die omgewing van Karasburg, Namibië. My ouma is oorspronklik van Namibië en ook van Karasburg se omgewing. My Oupa - hy is ook afkomstig van Afrika wêreld van 'n groot trek deur die land tot in SuidAfrika. My Oupa is 'n Griekwa Kleurling, sy taal is Koitaal, 'n Namataal. My pa is ook 'n Tswana gemeng met Kleurling bloed. Sy kinders is almal gemeng Tswana, Kleurling Baster, dit bring ons nou uit op Kleurling. Ons kerkverband issie NG Kerk. Ons huistaal is Afrikaans. [My mother was a Baster-Coloured-Hottentot woman. Her name was Katrina De Wee. She came from the Karasburg district of Namibia. My grandmother was from the same part of Namibia, originally. My grandfather also came from somewhere in Africa and after a great trek came to South Africa. My grandfather is a Griqua-Coloured whose language is Khoe language, a Nama language. My father is a Tswana mixed with Coloured blood. His children are all a mixture of Tswana-Coloured-Baster, bringing us to Coloured. Our church affiliation is the NG (Dutch Reformed) Church. Our home language is Afrikaans.] (De Wee 2014:43-44)

Izak Kruiper, a traditional healer, also expressed the $\neq$ Khomani's complex fluid identities when asked during the Biesje Poort rock engraving recording project what language they speak:

Die ou N/uu taal. Maar wat ons praat is die Nama, dis baie gekoppel aan Afrikaans. So as jy nou Botswana toe gaan, dan kry jy Naro, die Naro is gekoppel met Tswana ... Nou dan kom jy en dan hoor jy bietjie Naro, bietjie N/n!ke, so hy's baie gekoppel met Tswana. Dan gaan jy Namibië toe en dan kry jy nou Damara, dis nou gekoppel met die Himba en met die Herero en die Nama ... $\mathrm{Ja}$, ander tale het ingekom, hy is maar ook 'n mengsel van, as ek by die Hollanders praat dan verstaan ek baie goed. By die 'German', dan moet ek nou weer baie mooi luister dat ek nou weer kan verstaan. Dan verstaan ek die 'German' so bietjie, want ek moet mos inpas. [The old $N / u u$ (a dialect of $N / n ! k e$ ) language. But what we speak is Nama. It is well-linked to Afrikaans. So if you go to Botswana now, then you get Naro, and Naro is linked to Tswana ...

4.The Kruiper family are of the $=$ Khomani San, Kalahari, historically from the Kgalagadi Trancen Transfrontier Park (KTP) the Northern Cape, South Africa. The Org family too are from the KTP area but presently living south of the KTP, on the Botswana side. The Org and Kruiper families are related through marriage historically and presently and the fence between the families is an unnatural boundary. 
Now then you come and hear a bit of Naro, a little N/n!ke, so it is very well-linked to Tswana. Then you go to Namibia and then you get your Damara, that is linked to Himba and with the Herero and the Nama ... Yes, other languages came in, it is also a mixture of - if I talk to the Dutch then I understand very well. With the German, I have to listen very carefully so that I can understand. Then I understand the German a little bit, because I have to fit in.] (Kruiper 2013:57)

However, a consistent element within the Kalahari People's world is the natural landscape that moulds identity as the people mould it (MacCullam 2005, 2015). It could thus be argued that, specifically since colonial times with the shifting categorisation of indigenous peoples and changing colonial political powers (Adhikari 2009), the landscape, including its fauna and flora, is the one enduring point of identity reference for the people north of the !Garib/Orange River. Specifically, the people identify with the river and the desert sands; the landscape, rain animals and the celestial bodies. This is supported by their continued incorporation of geometric images, interpreted as both denotative and connotative icons of the landscape (Lange 2011a), in the area's art namely rock engravings and present-day ostrich eggshell engraving and burning on wood (Jacobson 2006; Lange 2006).

A small reception study of geometrics conducted in the area reflected that geometric images are not only read crossculturally, as material landscape features such as roads and rivers or celestial beings, for example the sun and stars, but also as animals and plants linked to transformation specifically regarding images such as the snakes, porcupines and !nabba [truffles] (Lange et al. 2008, 2011a). The geometrics included in the reception study were based on geometrics interpreted as first stage trance entoptic signs by David LewisWilliams (1990) in his Shamanistic rock art interpretation, as well as geometrics found in rock art and ostrich eggshell decoration. The engraved geometrics are also linked to both Water Snake oral narratives and sites in the landscape where female puberty rites were held (Lange 2011a; Morris 2012, 2014). Geometric images bridge the cosmic, the natural and the domestic; the communal and the personal. They comprise in visual literacy what myth does in oral literacy; communication of the universal in and appealing to the particular, local or personal (Lange et al. 2008, 2011a). It is proposed that as they are read cross-culturally, specifically as relating to nature

as metaphors of transformation and transition that they are included spiritually in rituals not just as decorations but as holistic metaphors of the transformative or transitional physical and social aspect of the occasion as well as nature and the spiritual power/s that control/s it or is one with it. (Lange 2014)

Cognisance of these spiritual elements manifested in the Kalahari People's art and oral narratives and their relationship to the landscape is essential for social change projects, especially if they include infrastructural changes to the landscape. This is of relevance to environmental impact assessments where the impact on the cultural heritage (including the intangible) should be investigated (Hattingh 2007).
The landscape often features in South African stories (Jenkins 2004), whether folk tales or oral reminiscences, and land has become the focus of many development and social change projects in South Africa with the post-1994 land redistribution programme (Hitchcock 2002; Magome \& Murombedzi 2003; Ramutsindela 2003; Rogerson \& Visser 2004). Cultural identity, indigenous ontology and spirituality are inextricably linked with land (Kincheloe \& Steinberg 2008).

Understanding the relationships indigenous people have with the land on which projects are implemented is vital, if local partners are to truly form part of a partnership where their development discourse and expectations are taken into consideration. (Dyll-Myklebust 2014:526)

The remainder of this article will thus present some observations sourced from artistic expressions, including stories that illuminate this dynamic relationship between social change, landscape, spirituality and shifting identities.

Keidebees, a suburb in Upington was an 'onderdorp', as previously discussed in this article, and as such the equivalent of District Six in Cape Town, Sophiatown in Johannesburg and Cato Manor in Durban. In pre-'dompas'/passbook days it was a racially inclusive area. Martha van Rooi, one of the Water Snake storytellers, now of Rosedale, Upington, tells of how one day they were separated like 'die bokke van die skape' [goats and sheep] (M. van Rooi, Interviewed by Mary Lange at Keidebees, Upington, 1998). The town's central business district had expanded and Keidebees was too close for comfort. Townships were built; one for mixed race people was just out of town and one for black people was built a few kilometres out towards the desert. Martha and her sister Nana tell of how passbooks were issued and individuals categorised through physical features, homes bulldozed, and friends and sometimes families torn apart (De Wee 2014; M. van Rooi, Interviewed by Mary Lange at Keidebees, Upington, 1998).

February 2004 saw the completion of successful land claims at Keidebees and a new suburb sprung up that once more included people of mixed racial identities. Many of those who made successful land claims sold their land as they had developed new roots and a sense of place, influenced by spiritual beliefs and practices, in the outlying areas. The Keidebees plot of land closest to the town was, however, still vacant in 2011. Only rubble remains, a broken cup here, a brick there as testimony of the informal settlement that existed before. A revisit to that open plot of land in Keidebees by the sisters Martha and Nana for the first time since the forced removal resulted in their spontaneous singing out over the vacant land in Afrikaans: 'O Keidebees, O Keidebees, jou sal ons lief bo alles!' [Oh Keidebees, Oh Keidebees, you we will love above all!] (M. van Rooi, Interviewed by Mary Lange at Keidebees, Upington, 1998). They sang it to the tune of the Christmas Carol 'Oh Christmas tree, Oh Christmas tree!' that was originally the German traditional folk song 'O tannenbaum, O tannenbaum!' ${ }^{5}$ (see Figure 1). The song emphasises the evergreen fir tree as a symbol of faithfulness

5.From hittp://german.about.com/library/blotannenb.htm 


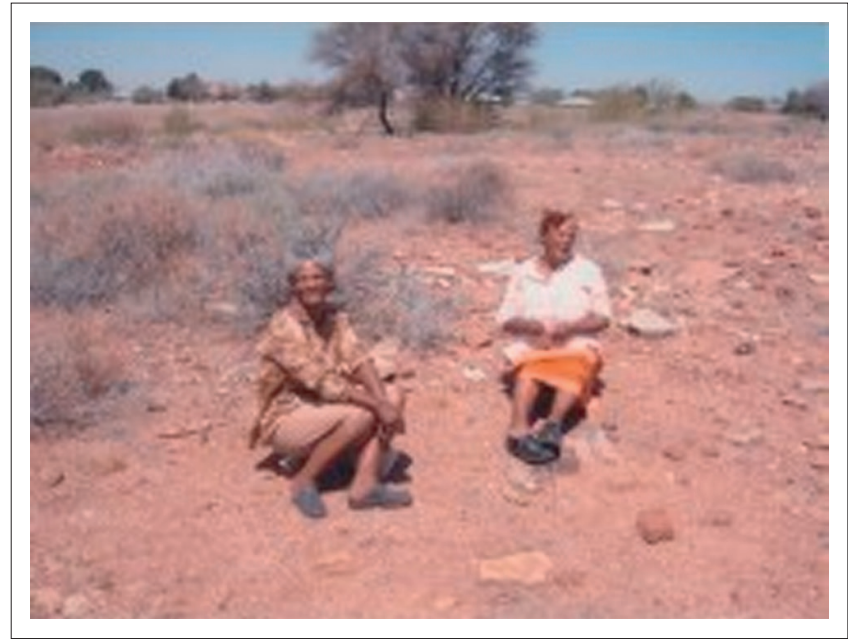

Source: Photo taken by Mary Lange

FIGURE 1: From left to right Martha van Rooi and Johanna de Wee. Water storytellers at Keidebees vacant land.

and constancy of God to mankind in Christianity (Steiner 2013). Besides the use of the song for political resistance, as was common during the apartheid clampdown on freedom of speech (Schurman 2008), it also highlights art, in this case a song, as an expression of people's spirituality, the complexities of cultural roots and identity, and it underlines the view of the landscape as a pivotal aspect of identity formation.

The use of a Christmas carol tune points to a spiritual identity manifested in Christian practices; however, Martha and Nana were the main contributors to a record of stories that reflect a continued belief in a water deity located in the Orange/!Garib river, namely the Water Snake (Lange 2014; Lange et al. 2008). These oral narratives, as well as the rock engravings from the Upington, area reflect differences and similarities to traditional San cosmic beliefs. The similarities reflect a continued spiritual belief in the Water Snake's transformational characteristics:

Hy verander hom mos in enige ding - dis die storie ... In 'n ou skaaplammetjie wat blêr, en 'n kind wat daar sit, jou eie kind of jou suster, en nou sien jy ... nou, nou, wat soek hy oppie rivier? Dis enige soort ding, sien jy nou, dis 'n mens ... of 'n hoed ... of 'n iemand wat vir jou roep oppie river. [He can of course change himself into anything; that is how the story goes! Into a bleating lamb, or a child sitting over there - your own child or your sister, and you might wonder what she is doing at the river... It's anything. Do you understand now? It's a person ... or a hat ... or someone calling you from the river.] (Malo 2014:18)

The differences include 'a binary oppositional belief ... whereby the water deity comprises positive and negative qualities' (Lange 2011a:152). However, despite the reflection of traditional spiritual beliefs through stories it became evident in discussions with the women that their spirituality is complex and as such does not necessarily include compartmentalised traditional and Christian beliefs, but rather bridges these. Storytelling itself is considered not only a physical manifestation of spirituality but an activity that can lead to a state of altered consciousness or story listening trance phenomenon (Sturm 1999), and therefore, as previously mentioned, the present retelling, as in the past, can be considered a practice that promotes individual wellbeing and social cohesion. Nana de Wee requested to include stories about Jesus from the biblical Apocrypha when a video was made of the Water Snake stories. She focused on the video as an oral heritage record for her grandchildren and children to follow. This was evident not only in the manner in which she related the story of the child Jesus and the dragons, but also that she directly addressed the camera and said 'Nou luister hier my kinners' [Now listen here my children] (J. De Wee, Interview filmed by F.J. Lange at Upington Oasis Lodge, 2005). In discussions with the women it became apparent that

the majority of the women believe that as long as they have a strong belief in Jesus then they have nothing to fear from the Water Snake. They believe that all natural forces and spirits bow before God in the same way that the dragon in the cave bowed to the child Jesus in the story Nana related on camera. They still, however, respect old traditions and rituals. (Lange 2014:1)

These shifts in identity and reconfiguration of traditional beliefs with Western Christianity is evident in the $\neq$ Khomani member, Hans Padmaker's merging of Thukwa, and 'the Messiah'. This is evident in Padmaker's response $(\mathrm{H}$. Padmaker, Interview with Lauren Dyll at!Xaus Lodge, KTP, 30 January 2007) to a question about the possible benefits of the $\neq$ Khomani and Mier community-owned, but privately operated, lodge in the Kalahari, and sheds light on how the process of development is signified in terms of spirituality:

I think there are a lot of advantages for the ¥Khomani. Although some people have been sceptical for some time, you know, because of the [lodge's] remoteness ... But if it could be possible and trust not only in our abilities or the operator's ability, or $¥$ Khomani CPA, or Mier Municipality. But also depend on the Messiah, or as the Bushmen say Thukwa ... you see trust in God the creator of you and I. And I believe that despite our faults and our sins and things like that we could get somewhere.

For Padmaker the lodge's success is not only dependent on the partners' abilities, but also on the forgiveness of Thukwa (Tsui । | Goab), a Khoe 'supernatural being'. Padmaker also referred to practical elements in terms of what the lodge (management) would need to do to be successful. Directly following his explanation of the role of the Messiah or Thukwa, he acknowledged the importance of marketing and the need for skills development. Padmaker's development narrative illustrates the interaction between the practicalities of daily life in making a success of a development initiative and the role of a deity in 'allowing' this process to happen (Dyll-Myklebust 2014).

Similarly, the women of Nguni language (including isiXhosa and isiZulu) and mixed ancestry who contributed to the Water Snake stories collection reflected a hierarchical belief in the power of God/Jesus as the supreme power, followed by that of the ancestors, and therefore a need to still practice ancestry rituals such as the burning of imphepho (Sixaxa 1998). The oral recording of the Water Snake stories in 1998 


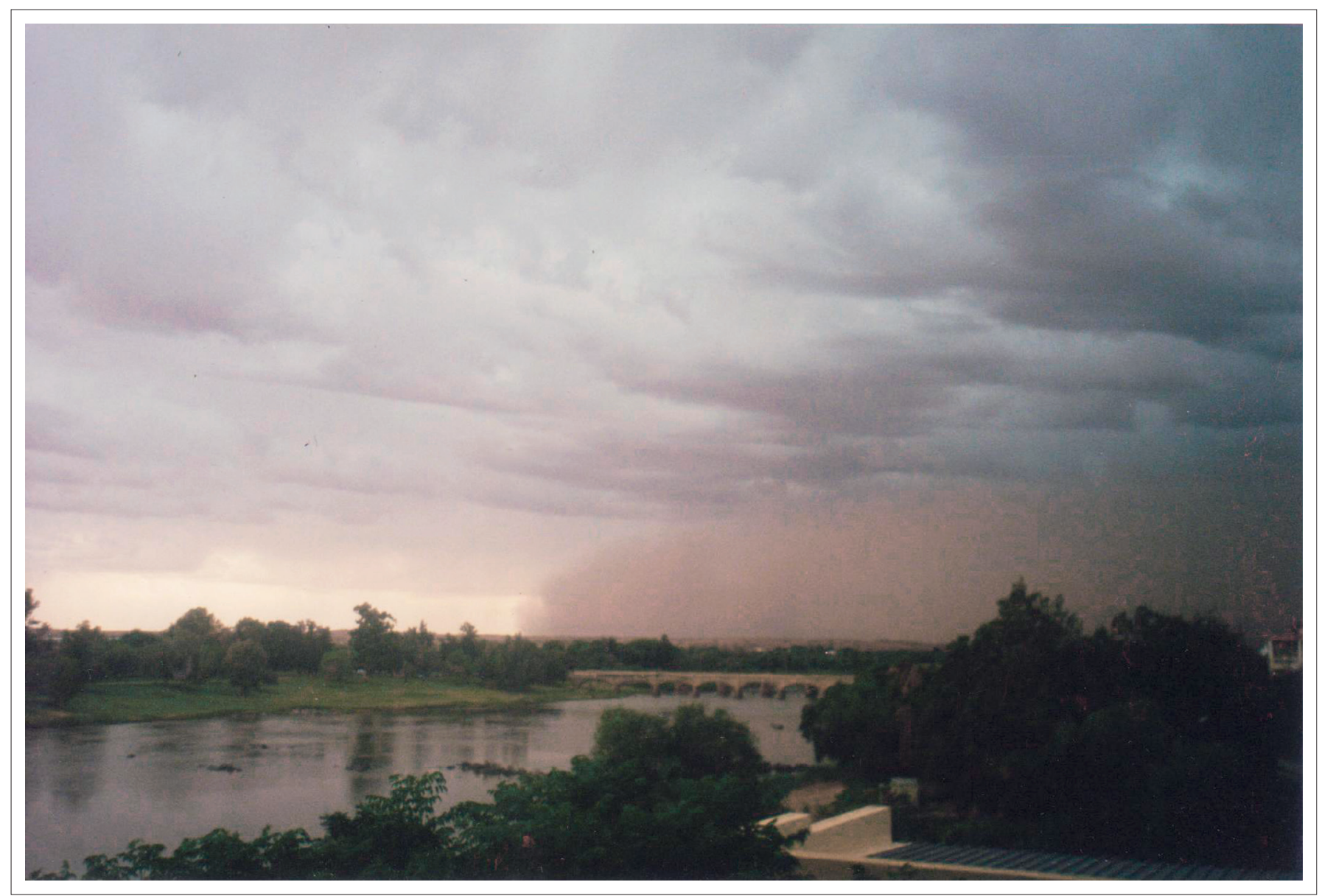

Source: Photo taken by Mary Lange

FIGURE 2: Bridge from Upington to the Eiland over the The Orange!Gariep River. A dust storm moves across the landscape.

also prompted Bessa Sandhlana/Sixaxa to want to share more regarding her and her communities' spiritual beliefs. This she did by providing a homemade video of the women's role in the young men's circumcision initiation ceremony. This video was her visual equivalent to the recording of oral narratives/stories on her heritage and similarly proved to be a source of her and her people's spirituality and links to the land. In her oral reminiscences Bessa related that there were individuals from Keidebees who chose not to be categorised as Coloured despite the 'perceived' social benefits in the apartheid hierarchy. These choices were influenced by spiritual beliefs and related cultural practices. With the introduction of locomotives to the Green Kalahari area from the 1920s (Boonzaaier 2008), a number of isiXhosa-speaking men moved in from the Eastern Cape. The practice of male circumcision, by the isiXhosa-speaking men, is influenced by the belief that there is spiritual unity between the practice and the ancestors (Mavundla et al. 2009). Therefore, the initiation ceremony promotes spiritual, family and communal unity, a sense of belonging and social identity (Mavundla et al. 2009), and underlines why some people chose to rather not be classified as Coloured but rather chose to go to the black township so that they were with a community where their ancestral rituals could be practiced (Sixaxa 1998). It also clarifies why some people chose to rather remain in the townships, where they had built spiritual ties to the landscape, than move back to Keidebees despite successful land claims.

The Orange/!Garib River is the common landscape feature, previously discussed as a constant that moulds identity and influences the Water Snake storytellers (see Figure 2). The women's spiritual beliefs, despite their differing mixed racial and cultural identities, have in common that the Water Snake is a powerful deity that manifests itself positively in soft rain and negatively in harsh storms and drownings (Lange 2011a). They also all believe that in the home of the Water Snake under the water there is another world where people who do not come out of the water live as we do on earth. The one major difference in the spiritual practices of the storytelling women related to the Water Snake is that the Nguni descended women include a sacrificial ritual whereby a 'bees' [ox/beast] is sent into the river for the Water Snake in order to ask for the return of someone who has gone into the water and has not returned (Sixaxa 2014). Although the Khoesan descended Water Snake storytellers from Upington did not include this sacrificial element in their presentday stories, there are numerous rock paintings attributed to Khoesan artists that include an image of a bovine-type creature being led into a river or waterhole, often by a therianthropic type image. These images are interpreted by some as illustrations of San myths (Solomon 1998), but the 
dominant interpretation is that the image symbolises the trance state of a shaman (Lewis-Williams 1990). The two interpretations need not be mutually exclusive (Lange 2011a). Once more it is through the sharing of the intangible, the oral aesthetic heritage, that the similarities and differences in spirituality and related attachment and use of the landscape can be appreciated.

Kalahari people who identify themselves as $\neq$ Khomani San, or as they prefer to be called "Boesman", are hunter-gatherer descendants who also believe in the Water Snake (Org 2011). The importance of landscape and spirituality as well as complex identities was further highlighted on the Biesje Poort rock engraving field trips. Jan Oeliset Org, from the Kalahari in Botswana, refers to himself as a Christian and he quotes the Old Testament, in particular, in his everyday discussions. However, he is a traditional healer and has knowledge of throwing bones, a divining practise that is usually associated with African Farmer traditional healers (Richter 2003). He named one of the rock engraving sites at Biesje Poort the 'baarmoeder' / the womb of the Water Snake. $\mathrm{He}$, like the women of mixed descent in Upington, also ascribed the terrifying weather experienced on the banks of the Orange/!Garib River one night as related to the Water Snake. He likewise emphasises the pervasive power and presence of God in all things, as well as God's role as a provider (Org 2011).

The harsh landscape and related extreme weather contrasted by the thirst quenching and cool rain on the banks of the Orange/!Garib River did not only elicit spiritual responses from the Kalahari San descendants but also from the visiting co-researchers (Lange 2011b). Similarly, descendants of European settlers in the Kalahari also include elements of indigenous spiritual beliefs. For example, in the poems of Afrikaans-speaking Euodia Beukes written about her life at Biesje Poort, she too pleads for 'she' or soft rain (Beukes 2013).

Any form of social change happens within a landscape. If spirituality is to become a meaningful consideration in research and in social change projects, it is important to dismantle the tension of the nature-culture relationship, usually viewed as a dichotomy in modern Western thinking. However, one must still be careful not to fall into essentialism and romanticism. All local people are connected to their land. Manulani Aluli-Meyer (2008) explains the importance of physical place and knowledge in understanding what is of value to local communities:

\footnotetext{
Indigenous people are all about place ... You grew in a place and you had a relationship with that place. This is an epistemological idea... One does not simply learn about land, we learn best from land. This knowing makes you intelligent to my people. How you are on land ... opens doors to the specificity of what it means to exist in a space and how that existing extends into how best to interact in it. (p. 219)
}

We agree with this statement, but the Kalahari People, and specifically the $\neq$ Khomani's relationship with their

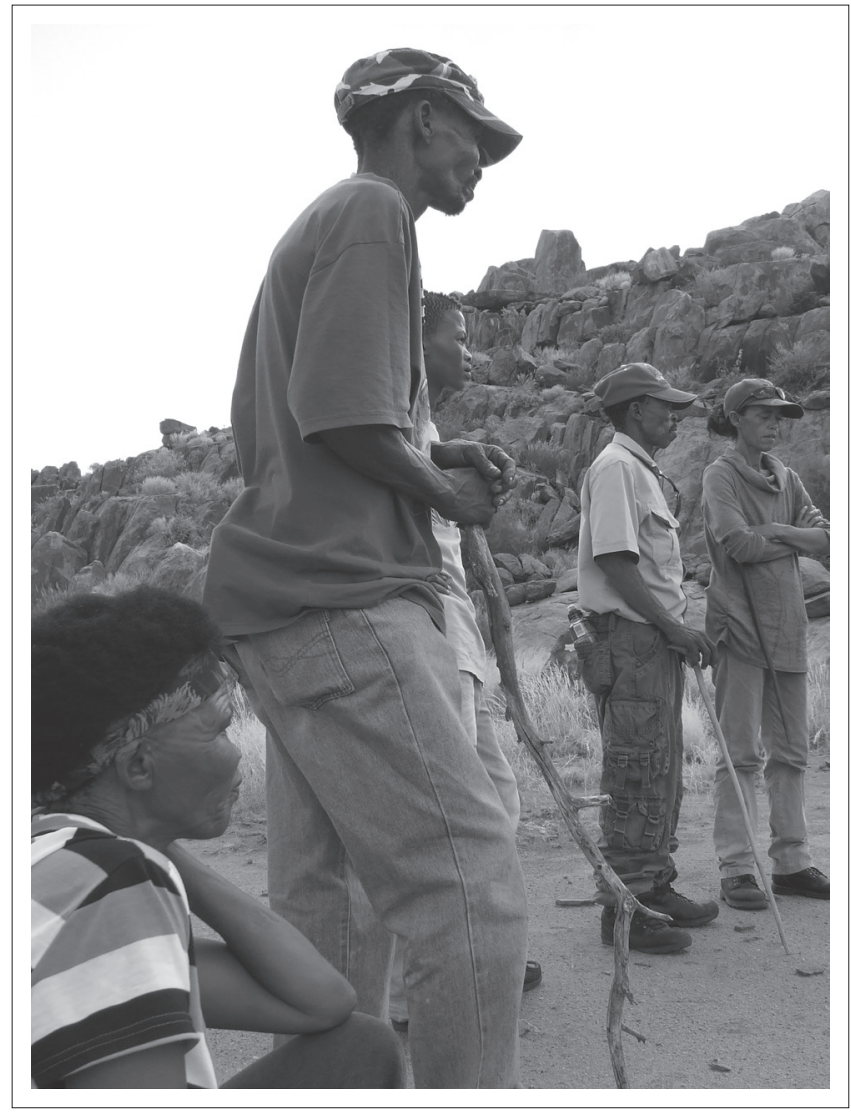

Source: Photo taken by Lauren Dyll-Myklebust

FIGURE 3: Biesje Poort team members add to indigenous knowledge.

landscape/nature, should not be viewed from an exclusively deterministic $^{6}$ and mechanistic sociological perspective (Wilson 1975, 1984). Their relationship to nature is constantly changing (as are their identities) as they are denied unlimited access to nature, as they historically had. An overlydeterministic perception on the relationship with nature here is dangerous as it ignores the relationship between society, history, local conditions, and political institutions; with behaviour. This denies the $\neq$ Khomani the agency to change and be anything other than a hunter-gatherer 'stuck in the past' as is promoted in popular culture. The everyday experiences of the $\neq$ Khomani negate the neat dichotomy of 'modern' and 'traditional' (see Figure 3). According to Robins (2001):

The hybridized conditions of everyday life in the Kalahari include 'local' knowledge practices and identities, a lack of water but access to 'exogenous' cyber-technologies, fax machines, cell phones and international indigenous peoples' conferences. (p. 835)

Liana Müller Jansen (2013:21), a landscape architect within the Biesje Poort project, provides a useful definition of landscape valuable to social change communication

the word 'landscape' includes people, human beings in relation to the environment, at its core ... [A person's] inner landscape merges the perceived experience of the place with the imagined symbolic meaning of the place to the individual. Landscape,

6.Nature determines behaviour 


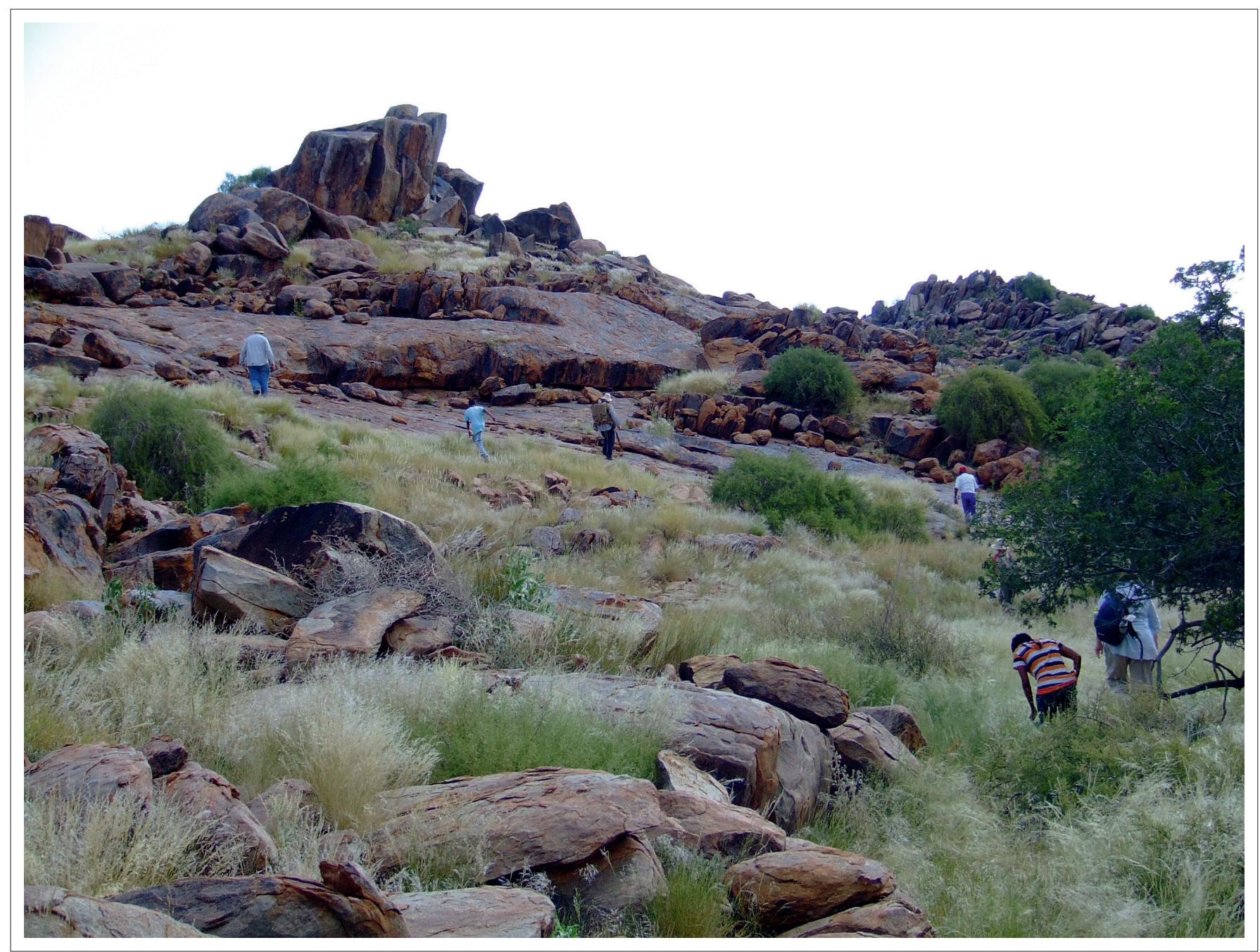

Source: Photo taken by Lauren Dyll-Myklebust

FIGURE 4: Biesje Poort team walk the land and snake up the koppie.

in a meaningful sense, thus encompasses environment plus relationships that emerge from or exist in a place.

Müller Jansen (2013, see also Casey 2000; Ingold 2000) notes the strength of the method in walking the land with Kalahari participants at Biesje Poort:

It is ... not only by being in the landscape that allows one to perceptually engage and gather knowledge, but specifically by moving through the landscape that the full spectrum of body sensing in conjunction with perception allows one to gather the clues to meaning. (p. 23)

It is within this relationship that different meanings of landscape are constructed (see Figure 4). The constructivist school of thought recognises that impressions about nature, for example, are socially constructed and imagined, as opposed to the earlier sociobiological views (Wilson 1975, 1984) that are arguably aligned to dominant secular 'scientific' perspectives which have been deemed deterministic and mechanistic. Constructivism allows the man-nature-culture (and in this case spirituality) relationship to be problematised in valuable ways that may prove beneficial to social change strategies that aim to alleviate poverty, facilitate conservation, or impart skills for empowerment.
Müller further tells of how during the 2013 field visit Kalahari crafters, Oeliset, Lys and Isak, would move away from the team and despite their suggestion to turn south the team continued to head up the hill in search of a rock art site. It was not found at the top of the hill. Müller Jansen (2013) reflects:

While walking up the hill, I knew the Kalahari participants had to be right; they understood the land. During the first [2011] fieldwork session and contact with the landscape, the Kalahari participants schooled themselves in the clues and keys of the landscape of where engravings might be, but also what they could mean. The resultant internal map they generated of the landscape is based entirely on perception, but specifically a bodily perception as generated through the act of walking the land. This reading of the landscape is enculturated - their elders have taught them how to read the landscape for certain signs. (p. 24)

Whether one is more inclined to attribute these perceptions to a biological and sentient ecology explanation or a constructivist explanation, it is important as social change practitioners to acknowledge that at the end of the day they point to multiple and valid interpretations of identity, spirituality and landscape that must be considered in approaching a project. The question is, how? 


\section{A brief 'how to': Taking note of nuance and establishing relationships}

Fieldwork is not 'neat', neither is 'social change', nor 'spirituality', and storytelling is cyclical and sometimes incomplete. It is thus our responsibility as academics and researchers to resist the 'ease' of neatly categorising such issues and to rather showcase the nuance in publications and reports and in seeking indicators for social change projects that acknowledge these nuances.

An explicit effort for noting this nuance can be done via adopting a reflexive and autoethnographic approach - a dramatic narrative that examines Self/Other relations in a research context and makes connections between the personal/micro experiences and larger structures (see Anderson 2006; Ellis \& Bochner 2000; Tomaselli, DyllMyklebust \& Van Grootheest 2013).

The storytelling studies discussed here adopted this approach and were facilitated by engaging with people with whom the researchers had built up long-term relationships as the authors had visited the Kalahari and Upington areas for more than 12 years. Many of these relationships had been built outside of a formal research space as the authors had facilitated a number of art and craft exhibitions in Durban for the Kruipers (Lange 2006) and an art and poetry publication for Belinda Org and her late husband, Vetkat Regopstaan Kruiper (Kruiper 2011, 2014). The impact of language barriers between researchers and storytellers in the field has been highlighted in the Engraved Landscape: Biesje Poort Many Voices project (Lange et al. 2013, see particularly Magongo 2013). In both the recording of the Water Snake stories and the Kalahari People's contribution to the Biesje Poort project, trust and participation was facilitated by the inclusion of the storytellers as full members in the project, and thus the traditional division of researcher/researched was dismantled. As such they were included in all phases of the project, from proposal writing (where relevant) and logistical planning, to vetting the final publication of their stories. The inclusion of their stories and the outcomes thereof was made transparent from the beginning through dialogue and discussion (Lange 2011a; Magongo 2013).

The need for trust that comes with time spent in building up a relationship before stories can be recorded is not underestimated by the authors, and the logistical implications appreciated. Trust in the Water Snake stories project resulted in the women feeling free to request that the author not be present when they recorded their stories (Lange 2011a). They set the time and chose the place where and when they would sit and record their stories (Lange et al. 2008). If the act of storytelling in itself can be a spiritual transformative, transcendent space that holds the potential for the promotion of well-being, then researchers need to consider where and when stories are told and that the attention given by the listener is significant (Sturm 1999). A flexible approach by the researchers resulted in a 'work-in-progress', non-linear, action research approach that reflected the cyclical and repetitive nature of stories and 'acknowledges the messiness of everyday lives, accepts the mistakes that are made, and resists neat resolutions to social problems' (Nicholson 2009a:274). It includes a 'person-centred approach to working with people' whereby each participant's view is taken into account and 'an ethic of care [which] means that participants are able to choose what stories they will share, and with whom and what they prefer to withhold' (Nicholson 2009a:270).

\section{Conclusion}

Social change practitioners and researchers need to engage with the multivocality of both past and contemporary manifestations of spirituality and a people's connection with land. The importance of this is expressed by Keyan Tomaselli (2013), a member of the Biesje Poort project:

The enduring blind spots in Western science are of cosmology, the spiritual and religious world, and of the ancestral realm. For our hosts, those whom we employed to participate as cointerpreters of our joint research survey/journey, this lack is puzzling. To dismiss this sacred dimension where causation is attributed to other realms invisible to Western science is to dismiss their ontology, their ways of being, thinking and doing. That would be offensive to them. (p. xii-xiii)

The field of spirituality includes the debate of the relationship between religion and spirituality (Ingersoll 1994). In the examples provided above, of the Water Snake storytellers and the Biesje Poort Kalahari participants, to know that their religious identity is Christian without further investigation would ignore the significance of geographical features in their spiritual beliefs and related implications in individual and communal social change as well as infrastructural development of the land. Knowledge of the spirituality and thus identity of individuals and communities within a specific context of time and place are essential in order to understand the links or views of the community to the land. Both projects discussed here embraced this approach in both methodology (recording stories via participatory communication methods in heritage field recording) and outcome (inclusion of all team voices and the publishing of First People's voices under their own names) (Lange 2011a, 2014; Lange et al. 2013). What is clear from this study is that it is not sufficient to refer to frozen stereotypical identities related to race or geographical location, nor to only note the religion of an individual or a community within a social change initiative. Further the study highlights stories as a significant expression of spirituality and the importance of recording them in social development projects.

\section{Acknowledgements Competing interests}

The authors declare that they have no financial or personal relationships which may have inappropriately influenced them in writing this article. 


\section{Authors' contributions}

This article is a combination and reworking of the authors' (M.E.L. [ARROWSA] and L.D-M. [ARROWSA]) presentations offered at Spirituality conferences in Prague and Pretoria. Data includes findings from fieldwork in the Kalahari. Fieldwork at Biesje Poort was funded by the South African National Heritage Council (NHC). Opinions expressed are that of the authors, not the NHC.

\section{References}

Adhikari, M., 2009, Burdened by race: Coloured identities in Southern Africa, UCT Press, Cape Town.

Aluli-Meyer, M.A., 2008, 'Indigenous and authentic: Hawaiian epistemology and the triangulation of meaning', in N.K. Denzin, Y.S. Lincoln \& T. Tuhiwai Smith (eds.) Handbook of critical and Indigenous methodologies, pp. 217-232, Sage, Thousand Oaks, CA.

Anderson, L., 2006, 'Analytic autoethnography', Journal of Contemporary Ethnography 35(4), 373-395. http://dx.doi.org/10.1177/0891241605280449

Bah, U., 2008, 'Rereading the passing of traditional society. Empathy, orthodoxy and the Americanization of the Middle East', Cultural Studies 22(6), 795-819. http:// dx.doi.org/10.1080/09502380701702599

Beukes, E., 2013, Riemvasmaak - hartland, harde land, Hemel \& See, n.p.

Boonzaaier, B., 2008, Tracks across the veld: A southern African rail safari, J.N.C. Boonzaaier, Warmbad/Bela Bela.

Casey, E., 2000, Remembering: A phenomenological study, Indiana University Press, Bloomington, IN.

Crisp, B.R., 2010, Spirituality and social work, Ashgate, Farham.

Crisp, B.R. \& Beddoe, L., 2013, Promoting health and well-being in social work education, Taylor \& Francis, New York, NY.

Denzin, N., Lincoln, Y.S. \& Smith, L.T. (eds.), 2008, Handbook of critical and indigenous methodologies, Sage, London.

De Wee, J., 2014, 'The Storytellers/Die Vertellers', in M.E. Lange (ed.), Water stories: Original! Garib narrations about the water snake, pp. 43-44, UNISA Press, Pretoria.

Dodge, R., Daly, A.P., Huyton, J. \& Sanders, L.D., 2012. 'The challenge of defining wellbeing', International Journal of Wellbeing 2(3), 222-235. http://dx.doi. org/10.5502/ijw.v2i3.4

Dutta, M.J., 2011, Communicating social change: Structure, culture and agency, Routledge, New York, NY

Dyll-Myklebust, L., 2014, 'Development narratives: The value of multiple voices and ontologies in Kalahari research', Critical Arts: South-North Cultural and Medid Studies 28(3), 521-538. http://dx.doi.org/10.1080/02560046.2014.929214

Ellis, M.H., 1990, Towards a Jewish theology of liberation: The uprising and the future, Orbis Books, Maryknoll, NY.

Ellis, C. \& Bochner, A.P., 2000, 'Autoethnography, personal narrative, reflexivity: Researcher as subject', in N.K. Denzin \& Y.S. Lincoln (eds.), Handbook of qualitative research, 2 nd edn., pp. 733-768, Sage, Thousand Oaks, CA.

Ellis, W., 2014, 'Simulacral, genealogical, auratic and representational failure: Bushman authenticity as methodological collapse', Critical Arts: South-North Cultural and Media Studies, 28(3), 493-520. http://dx.doi.org/10.1080/0256004 6.2014.929213

Esack, F., 1997, Qurán, liberation and pluralism: An Islamic perspective of interreligious solidarity against oppression, Oneworld Publications, Oxford.

Figueroa, M.E., Kincaid, D.L., Rani, M. \& Lewis, G., 2002, Communication for socia change: An integrated model for measuring the process and its outcomes, The Communication for Social Change Working Paper Series No. 1, The Rockefelle Foundation and CFSC, New York.

Grant, J. \& Dicks, A., 2014, 'Perceived benefits of Freirean and grassroots comic workshops with three Bushmen communities', Communitas 19, 116-135.

Groen, J., 2009, 'Moving in from the fringes of the academy: Spirituality as an emerging focus in the Canadian professional Faculties of Business, Education, and Social Work', The Journal of Educational Thought (JET) / Revue de la Pensée Éducative 43(3), 223-244, viewed 06 February 2015, from http://www.jstor.org/ stable/23765478.

Guion, D.S., 2008, 'A study of spirituality in contemporary visual art and foundations funding', PhD thesis, Philosophy in the Graduate School of The Ohio State funding', Ph
University.

Gumucio-Dagron, A. \& Tufte, T. (eds.), 2006, Communication for social change anthology: Historical and contemporary readings, Communication for Social Change Consortium, South Orange, NJ.

Guttiérez, G., 1973, A theology of liberation: History, politics and salvation, transl. S.C. Inda \& J. Eagleson (eds.), Orbis Books, Maryknoll, NY.

Hall, S., 1992, 'The question of cultural identity', in S. Hall, D. Held \& A. McGrew (eds.) Modernity and its futures, pp. 274-316, Polity Press, Cambridge.

Hall, S., 1997, Representation: Cultural representations and signifying practices, Sage, London.
Hattingh, N., 2007, 'Heritage impact assessment of Cornubia residential and commercial development, Umhlanga, KwaZulu-Natal, South Africa', by Ethembeni Cultural Heritage for NMH Consulting, 23 May.

Hitchcock, R.K., 2002, “'We are the First People”: Land, natural resources and identity in the Central Kalahari, Botswana', Journal of Southern African Studies 28(4), 797-824. http://dx.doi.org/10.1080/0305707022000043520

Hocheimer, J., 2011, 'Communication, spirituality and the sharing of meaning', paper presented at the Global Conference on Spirituality in the 21st Century: Theory, Praxis and Pedagogy, 18-20 March, Prague.

Hodder, I., 1999, The archaeological process: An introduction, Blackwell Publishers, Oxford.

Hodder, I., 2010, 'Cultural heritage rights: From ownership and descent to justice and well-being', Anthropological Quarterly 83(4), 861-882. http://dx.doi.org/10.1353/ anq.2010.0025

Hoff, A., 1993, 'Die tradisionele wêreldbeskouing van die Khoekhoen', South African Journal of Ethnology 16, 1-9.

Hoff, A., 1997, 'The water snake of the Khoekhoen and the /Xam', South African Archaeological Bulletin 52, 21-37. http://dx.doi.org/10.2307/3888973

Ingersoll, R.E., 1994, 'Spirituality, religion, and counselling: Dimensions and relationships', Counseling and Values 38(2), 98-111. http://dx.doi.org/10.1002/ j.2161-007X.1994.tb00827.x

Ingold, T., 2000, The perception of the environment: Essays in livelihood, dwelling and skill, Routledge, London.

Jacobson, L., 2006, 'Namibian ostrich egg shells rediscovered', The Digging Stick 23(2), 15-17.

Jenkins, E., 2004, Sharing our stories, Cape Libre Sept/Oct 2004, pp. 12-15, viewed 10 March 2015, from http://www.westerncape.gov.za/text/2005/2/sep04 article2pg12_15.pdf

Kincheloe, J.L. \& Steinberg, S.R., 2008, 'Indigenous knowledge in education: Complexities, dangers and profound benefits', in N.K. Denzin, Y.S. Lincoln \& T. Tuhiwai Smith (eds.), Handbook of critical and indigenous methodologies, pp. 135-156, SAGE, London.

Knott, K., 1998, Hinduism: A very short introduction, Oxford University Press, Oxford.

Kruiper, I., 2013, 'Field discussions: Animal names, \#Khomani peoples, language, names of places and animals', in M.E. Lange, L. Müller-Jansen, R.C. Fisher, K.G. Tomaselli \& D. Morris (eds.), Engraved Landscape Biesje Poort: Many Voices, pp. 57, Tormentosa, Pretoria.

Kruiper, V.R., 2011, Mooi loop, ARROWSA, Durban

Kruiper, V.R., 2014, Mooi loop: The sacred art of Vetkat Kruiper, UNISA Press, Pretoria.

Lange, M.E., 2006, 'Tracking decorated ostrich eggshells in the Kalahari', Visual Anthropology 19, 371-388. http://dx.doi.org/10.1080/08949460600598745

Lange, M.E., De Wee, J., Van Rooi, M., Sixaxa, E., Saaiman, G. \& Malo, M., 2008, Water stories, Mel, Durban.

Lange, M.E., 2011a, Water stories and rock engravings: Eiland women at the Kalahar edge, SAVUSA Amsterdam.

Lange, M.E., 2011b, 'Tis an ill wind that blows nobody any good', SUBtext 15, 4-5.

Lange, M.E. (ed.), 2014, Water stories: Original! Garib narrations about the water snake, UNISA Press, Pretoria.

Lange, M.E., Müller-Jansen L., Fisher R.C., Tomaselli K.G. \& Morris, D. (eds.), 2013, Engraved landscape. Biesje Poort: Many voices, Tormentosa, Pretoria.

Leuthold, S., 1998, Indigenous aesthetics: Native art, media and society, University of Texas, Austin, TX.

Lewis-Williams, D.J., 1990, Discovering Southern African rock art, David Philip, Cape Town.

MacCullam, I., 2005, Ecological intelligence: Rediscovering ourselves in nature, Africa Geographic, Cape Town.

MacCullam, I., 2015, Memorial tribute, Ian Cedric Player, Hilton College, viewed 14 January 2015, from http://ian-mccallum.co.za/wp-content/uploads/2015/02/ IAN-PLAYERMEMORIAL.pdf

MacDonald, D., 2009, 'Identity and spirituality: Conventional and transpersonal perspectives', The International Journal of Transpersonal Studies 28(1), 86-107.

Magome, H. \& Murombedzi, J., 2003, 'Sharing South African National Parks: Community, land and conservation in Democratic South Africa', in W. Adams \& M. Mulligan (eds.), pp. 108-134, Decolonizing nature: Strategies for conservation in a post-colonial Era, Earthscan, London.

Magongo, M., 2013, 'Participatory communication: A tool for social and heritage development', in M.E. Lange, L.M. Jansen, R. Fisher, K.G. Tomaselli \& D. Morris (eds.), Engraved landscape. Biesje Poort: Many voices, pp. 93-100, Tormentosa, Gordon's Bay.

Malo, M., 2014, 'Die half-vrou, half-vis op Prieska', in M.E. Lange (ed.), Water stories: Original! Garib narrations about the water snake, p. 18, UNISA Press, Pretoria.

Marstine, J., Bauer, A.A. \& Haines, C., 2011, 'New directions in museum ethics', Museum Management and Curatorship 26(2), 91-95. http://dx.doi.org/10.1080/ 09647775.2011 .56670

Masoga, M.H. \& Kaya, H., 2011, 'Building on the indigenous: An appropriate paradigm for sustainable development in Africa', in G. Walmsley (ed.), African philosophy and the future of Africa cultural heritage and contemporary change, vol. 14, pp. 153-169, George F. McLean (General ed.), The Council for Research in Values and Philosophy, Washington, DC. (Series II, Africa). 
Mavundla, T.R., Netswera, F.G., Bottoman, B. \& Toth, F., 2009, 'Rationalization of indigenous male circumcision as a sacred religious custom', Journal of Transcultural Nursing 20(4), 395-404. PMID: 19587214, http://dx.doi. Transcultural Nursing 20(4),
org/10.1177/1043659609340801

Melkote, S.R. \& Steeves, H.L., 2001, Communication for development in the third world: Theory and practice for empowerment, 2 nd edn., Sage, London.

Morris, D., 2012, 'The importance of Wildebeest Kuil: A hill with a future, a hill with a past', in B. Smith, K. Helskog \& D. Morris (eds.), Working with rock art: Recording, presenting and understanding rock art using indigenous knowledge, pp. 228-245, Wits University Press, Johannesburg.

Morris, D., 2014, 'Narrating Biesje Poort: Negotiating absence of storyline, vagueness and multivocality in the representation of Southern Kalahari rock engravings', Critical Arts: South-North Cultural and Media Studies 28(4), 648-669. http:// dx.doi.org/10.1080/02560046.2014.929222

Müller Jansen, L., 2013, 'Reading the Biesje Poort landscape', M.E. Lange, L. MüllerJansen, R. Fisher, K.G. Tomaselli \& D. Morris (eds.), Engraved landscape. Biesje Poort: Many voices, pp. 21-41, Tormentoso, Gordon's Bay.

Nicholson, H., 2009a, 'Re-locating memory: Performance, reminiscence and communities of diaspora', in T. Prentki \& S. Preston (eds.), The applied theatre reader, pp. 268-276, Routledge, London.

Nicholson, H., 2009b, Theatre and education, Palgrave, London.

Org, O.J., 2011, 'Biesje Poort: A place of birth', SUBtext, 15, 15.

Prado, S., 2010, 'Orality and immaterial cultural heritage. An introduction', proceeding s of the International Conference on Oral Tradition, 11-13 November, Ourense, Concello de Ourense.

Ramutsindela, M., 2003, 'Land reform in South Africa's national parks: A catalyst fo the human-nature nexus', Land Use Policy 20, 41-49. http://dx.doi.org/10.1016/ S0264-8377(02)00054-6

Republic of South Africa, 1999, National Heritage Resources Act, Act 25 of 1999, Chapter 111 Schedule (xxi) - 'Living heritage'.

Richter, M., 2003, 'Traditional medicines and traditional healers in South Africa', discussion paper prepared for the Treatment Action Campaign and Aids Law discussion paper prepared for the Treatment Action Campaign and Aids Law Trajitional_Medicine_briefing.pdf.

Robins, S., 2001, 'NGOs, Bushmen and double vision: The ${ }^{1}$ Khomani San Land Claim and the cultural politics of "community" and "development" in the Kalahari', Journal of Southern African Studies 27(4), 833-853. http://dx.doi. org/10.1080/03057070120090763

Rogerson, C.M. \& Visser, G. (eds.), 2004, Tourism and development issues in contemporary South Africa, Africa Institute of South Africa.

Schurman, A., 2008, 'The beat that beat apartheid: The role of music in the resistance against apartheid in South Africa', Stichproben. Wiener Zeitschrift für kritische Afrikastudien 14(8), 17-39.

Servaes, J. (ed.), 2008, Communication for development and social change, Sage, New Delhi.

Simões, A., 2001, 'Issues of identity in relation to the Kalahari Bushmen of Southern Africa: A comparative analysis of two different Bushmen groups during the late 1990's and into 2001', MA dissertation, Graduate Programme in Culture, Communication and Media Studies, University of Natal, Durban.
Sixaxa, E., 1998, Interview: The Water Snake and Nguni beliefs in Upington.

Sixaxa, M, 2014, "n Bees vir die Waterslang: Bessa' , in Water stories: Original! Garib narrations about the water snake, bl. 32, UNISA Press, Pretoria.

Smith, A.B. (ed.), 1995, Einiqualand Studies of the Orange River Frontier, UCT Press (Pty) Ltd, Rondebosch.

Solomon, A., 1998, The essential guide to San rock art, David Phillip, Cape Town.

Spivak, G., 1988, 'Can the subaltern speak?', in C. Nelson \& L. Grossberg (eds.) Marxism and the interpretation of culture, pp. 271-313, Macmillan, London.

Steiner, E.F., 2013, God is present and faithful: Homily background for fourth Sunday of advent - Year A. Father Edward F. Steiner The Priest, from https://www.osv.com/ OSVNewsweekly/Article/Tabld/535/ArtMID/13567/ArticleID/11335/

Sturm, B.W., 1999, 'The enchanted imagination: Storytelling's power to entrance listeners', in School Library Media Research, vol. 2, American Association of Schoo Librarians, viewed 11 February 2015, from http://www.ala.org/aasl/slr

Teasdale, W., 1999, The Mystic Heart: Discovering a universal spirituality in the world's religions, New World Library, Navato, CA.

Tisdell, E.J., 2003, Exploring spirituality and culture in adult and higher education, Jossey-Bass, San Francisco, CA.

Tomaselli, K.G., 2005, Where global contradictions are sharpest: Research stories from the Kalahari, Rozenberg Publishers, Vrije Universiteit, Amsterdam.

Tomaselli, K.G., 2013, 'Setting the scene: What's in a landscape?', in M.E. Lange, L.M. Jansen, R.C. Fisher, K.G. Tomaselli \& D. Morris (eds.), Engraved landscape. Biesje Poort: Many voices, pp. xi-xvii Tormentosa, Pretoria.

Tomaselli, K.G. \& Dyll-Myklebust, L., (in press), 'Public self-expression: Decolonising the researcher-researched relationship', Communicatio: South African Journal of Communication Theory and Research.

Tomaselli, K.G., Dyll-Myklebust, L. \& Van Grootheest, S. 2013, 'Personal/ Political interventions via autoethnography: Dualisms, knowledge, power and performativity in research relations', in S.H. Jones, T.E. Adams \& C. Ellis (eds.), The handbook of autoethnography, pp. 576-598, Left Coast Books, Goleta, CA.

Ver Beek, K., 2000, 'Spirituality: A development taboo', Development in Practice 10(1), 31-43. http://dx.doi.org/10.1080/09614520052484

Wielenga, B., 1999, 'Liberation theology in Asia', in C. Rowland (ed.), The Cambridge companion to liberation theology, pp. 199-217, Cambridge University Press, Cambridge.

Wilber, K., 2000, Integral psychology: Consciousness, spirit, psychology, therapy, Shambhala Press, Boston, MA.

White, H., 1995, In the tradition of the forefathers: Bushmen traditionality at Kagga Kamma, UCT Press, Cape Town.

Wilson, E.O., 1975, Sociobiology: The new synthesis, Harvard University Press, Cambridge.

Wilson, E.O., 1984, Biophilia: The human bond with other species, Harvard University Press, Cambridge.

Winskell, K. \& Enger, D., 2014, 'Storytelling for social change', in K.G. Wilkins, T. Tufte \& R. Obregon (eds.), The handbook of development communication and social change, pp. 189-205, Wiley \& Sons, West Sussex. 